\title{
An Appraisal of Library Services Provision to Prison Inmates in Nigeria
}

\author{
By \\ OMAGBEMI, Clement 0 \\ Bells University of Technology, Ota \\ omaoma077@yahoo.com Phone: 08055200319 \\ $\&$ \\ ODUNEWU, Abiodun $O$ \\ Olabisi Onabanjo University, Ago-Iwoye. \\ bodunewu@yahoo.com Phone: 08034015303,08058872114
}

\begin{abstract} nearby public libraries.

\section{Introduction}

Prisons are established confinements for the safe keeping of those legally interned or awaiting trials. Whichever way is the case, except for those who are to be executed upon the pronunciation of death penalty on them; prisons are expected to transform and reform the interned towards the re-integration of the affected individuals into the larger society on completion of their terms. For prisons to achieve the objectives of reformation and rehabilitation, there is the need for the training and re-training of the inmates. Training and re-training desires exposure of the inmates to adequate and timely information.
\end{abstract}

Prisons like other correctional institutions deserve organized information provision centers like a library. This study examined library services provision in the south-western part of Nigeria. It was found out that despite their incarceration, inmates desires variety of information; whereas the library stock is grossly inadequate and managed by non-librarians. The study recommends among others readership promotion campaign, organized library visit by library associations to the prisons; as well as the provision of outreach services to the inmates by

Information is a major resource in the development of human beings and the world entirely. Iloeje (2001) submits that information is the heart of the world developments. He further explains that our increased access to timely, accurate, relevant, reliable and current information has been a significant precursor to our technological innovations.

Libraries are major custodian of information, as information is acquired, processed and stored for retrieval when the need arise. Anafulu (1998) posits that the library is the engine room and power house where information is collected, stored, processed, and retrieved for use. A library is a body of collected information brought together for the purpose of knowledge dissemination and utilization. (Ibegwam, A. 2003).

Prisoners and prison officials, as members of the larger community desire and deserve information on events in the larger world, personal development, health information etc. Libraries are therefore a must in all correctional institutions.
This submission is corroborated by the European Prison Rule 82 as cited by Grimes (2000), “every institution (prison) shall have a library for the use of all categories of prisoners, adequately stocked with a wide range of both recreational and instructional books, and prisoners shall be encouraged to make use of it. This study therefore is a probe into the availability or otherwise of information services to prison interns in Nigeria, using some prisons in the south-west as case studies.

\section{Need For the Study}

Prison inmates are members of the larger society whose movement are restricted. The prison aside serving as custody for convicted people doubles as a reformative and rehabilitative centre. Information, no doubt plays a vital role in the necessary because the findings will reflect the kind of attention the prison system in Nigeria enjoys from the public and policy makers. It is assumed the findings will either leave the policy makers fulfilled or further challenged; and bring about a general awareness for information needs of the interned.

\section{Objectives of the Study}

i. To identify the role of adequate information in reforming prisoners.

ii. To identify the need for professional dispensation of library services to inmates.

iii. To identify the adequacy or otherwise of library services provision to prison inmates in Nigerian using the selected prisons as case study.

iv. To probe into the prisoners perception of information towards their reformation and recreational activities. reformative and rehabilitative process. This study is 
v. To evaluate the efforts of the library association in the development and growth of prison libraries.

vi. To create a general awareness of the need for inmates to have access to information.

\section{Research Questions}

i. Who are the inmates?

ii. Do they have information needs?

iii. What role could information play in rehabilitating prison inmates?

iv. Are there library services for prison inmates in Nigeria?

v. Are the various stakeholders-libraries, library associations, governments, prison officials adequately aware of the role information could play in the life' of the interned?

vi. How adequate are the library services (if any) being currently rendered to prison inmates in Nigeria.

\section{Scope of the Study}

This study is limited to some selected, but prominent prisons in the south-west region of the country - Nigeria. The selected prisons are expected to be good samples, representative of other prisons in the country. The selected prisons are located in Ibadan, Oyo, Ijebu-Ode and Ilesha. The four towns, apart from being major towns in the south-west served as provincial headquarters during the colonial days. The Ilesha prison was actually established during the colonial days; thus making it one of the oldest in the south-west of Nigeria.

\section{Significance of the Study}

This work is an attempt at evaluating the information services provision at the Nigerian prison libraries using the south-western area as a case study. It also attempts a probe into the perceived impact of information on the reformation and recreation activities of the prisoners.

The findings would therefore be beneficial to the country's leadership; and particularly the prison authorities in the decision to provide the interned with adequate but censored information or otherwise.

\section{Literature Review}

Prisons, like other segments of the universal community deserve functional libraries towards the provision of information resources for the prison inmates and the prison officials. Oketunji (2005) submits that libraries are built and maintained to provide information resources for a specific, defined community. As such, like academic libraries, school libraries et cetera; we have prison libraries.
Advocacy for adequately maintained, accessible prison libraries have been enjoying serious attention worldwide. For example, Curry, Wolf, Boutilier and Chan (2003) conducted a nationwide survey of the libraries in Canada's 51 minimum and maximum security federal correctional institutions. The survey revealed that the prison libraries were meeting offenders' needs for recreational, cultural, educational and informative material. Can this be said of prison libraries in Africa? Our academic libraries lack enough fund to make them adequate information research centres; talk less of services to those confined. Canadian prisoners, despite what looks like an excellent situation still believe that there was much room for improvement in funding for staff and collections. They felt that their libraries were undervalued within the prison administration. (Curry et al 2003). In the United States on the other hand, Shirley (2003) found out that standard library services delivery in prison libraries was being impeded by security concerns and limited budgets. If funds have been noticed to be the major challenge to prison libraries in the developed world; the case of the developing counties should therefore be a concern as many of the developing countries lack the financial strength of the developed ones. Hence, the need to conduct such survey in the developing countries.

The denial of information services especially to the permanently confined (the prisoners) can be detrimental to the objectives of the prison. The major objective of the prison to the convicted is reformation. Akpe (2004) supporting this claim, posits that the key element in prison administration is to reform and recover the convicted from a life of crime to path of rectitude. Daramola (2004) supports Akpe's submission when he submits that the main aim of imprisonment is for the safe custody of those legally interned and the detection of the cause of the anti-social behaviour that led to the incarceration with a view to transforming and reforming the interned. From the foregoing, it is obvious that the prison serves the dual role of custody of convicted prisoners, remand prisoners (awaiting trials) and detainees, and a reformative institution.

However in Nigeria, the prison being characteristically a closed system receives little attention from the public and policy makers, and as an arm of the criminal justice system, the prison deserves utmost attention (NPS/DFID 2002). This neglect has called for several initiatives by nongovernmental organizations (NGO) to attract members of the public to their social responsibilities to this special people. 
The prison was established to exploit diverse programme such as adult and remedial education for inmates, skills and vocational training, religious instruction, recreational and attitude change towards the achievement of the information and rehabilitation of inmates; so as to facilitate their social integration into the society after jail terms (Daramola 2004). One should assert that these goals need adequate provision and utilization of information. The library, if well developed will provide the information support needed for the achievement of the prison tasks. The use of books and other print and non-print materials (bibliotherapy) in reformation of individuals have been found useful in mental patients and prisoners (Rubin 1978); as cited by Jarjoura and Krumholz (1998). Rubin actually defined bibliography as a program of activity based on the interactive processes of the use of print and non-print materials whether imaginative or informational, facilitated by a librarian or other professional to achieve insight into normal development or to effect changes in emotionally disturbed behaviour.

Dixen and Thorsen (2001) wrote that prison libraries provide an important means of self improvement for inmates. They can act as a supplement to educational programs and can lead to better work opportunities, which in turn creates more stable and productive citizens". They further asserted that many believe that libraries are vital to the rehabilitation of the prisoners helping them to strengthen character and lessening the rate of recidivism (returning to prison). One may then conclude that the library has a major role to play in the reformation and rehabilitation of prison inmates. Imade's (2005) submission that "a twentyfive (25) capacity cell has about eighty-six (86) inmates, the prison is congested and is only opened once in a week, no regular bath is allowed, inmates are underfed, meals are not well prepared. The situation is so terrible that some inmates incited a riot in 2002". James Imade was a detainee without trial for eleven (11) years. The question - How can people who do not have regular bath use libraries readily comes to mind.

\section{Research Methodology}

The population for this study is the inmates of selected prisons in the south west area of Nigeria. In eliciting relevant information, the questionnaire tool as well as observation method was employed. The questionnaire were administered with the assistance of the prisons welfare officers who selected inmates that can read and write; and willing to attend to the questionnaire. Seventy questionnaires were administered and at the point of analysis, only sixty-two (62) representing $88.5 \%$ were found usable.

Results And Discussion

Table 1: Prison Surveyed, Questionnaire distribution and usable returns.

\begin{tabular}{|l|l|l|}
\hline Prisons & $\begin{array}{l}\text { No of Questionnaire } \\
\text { Distributed }\end{array}$ & Usable Returns \\
\hline NPS, Igbeba, Ijebu-Ode & $15(21.4 \%)$ & $15(21.4 \%)$ \\
\hline NPS, Agodi, Ibadan & $20(28.6 \%)$ & $18(25.7 \%)$ \\
\hline NPS, Lagbondoko, Oyo & $18(25.7 \%)$ & $14(20.0 \%)$ \\
\hline NPS, Oke Eso, Ilesha & $17(24.3 \%)$ & $15(21.4 \%)$ \\
\hline Total & $70(100 \%)$ & $62(88.5 \%)$ \\
\hline
\end{tabular}

*NPS - Nigerian Prison Services.

Table 2: Age Respondents

\begin{tabular}{|l|l|l|}
\hline Age Range (years) & Frequency & Percentage \\
\hline Below 20 & 05 & $8.1 \%$ \\
\hline $20-29$ & 32 & $51.6 \%$ \\
\hline $30-39$ & 16 & $25.8 \%$ \\
\hline 40 and above & 09 & $14.5 \%$ \\
\hline Total & 62 & $100 \%$ \\
\hline
\end{tabular}

Table 3: Educational Background

\begin{tabular}{|l|l|l|}
\hline Qualification & Frequency & Percentage \\
\hline SSCE/WASC & 32 & 51.6 \\
\hline NCE/OND & 18 & 29.0 \\
\hline HND/Bachelors & 07 & 11.3 \\
\hline Others & 05 & 8.1 \\
\hline Total & 62 & 100 \\
\hline
\end{tabular}


Table 1 above reveals the prison surveyed the number of questionnaire administered and the ones usable for data analysis. 70 questionnaires were distributed and only sixty-two $(88.5 \%)$ were useful.

Table 2 above reveals that majority of the respondents fall into the tender age of 20-29 years. This closely followed by the 30-39years age range. This suggests that crime rate is higher among these age grades. The reformative and rehabilitation objectives of the prison is assumed will be beneficial to those who fall between the ages of 18 and 30; as they still have a future if well reformed and rehabilitated.

Table 3 shows that majority of the respondents are holders of the Senior Secondary School Certificate. They constitute $51.6 \%$ of the respondents, while NCE/OND holders follow with 29\%. Higher National Diploma/Bachelors Degree holders constitute $11.3 \%$ while $8.1 \%$ claimed they posses professional certificates. Considering the fact that there are other inmates who are not literate, one is tempted to conclude that crime rate is prevalent among individuals without education and those with minimal level of education. However, the detainees of the Economic and Financial Crimes Commission (EFCC) as well as the convicted ones may swell the figures of the educated individuals in Nigerian prisons, as majority of them are public office holders who are expected to have average level of education. Unstructured discussions with some of the inmates reveal that factors such as joblessness, lack of future potentials, urge to 'cut corners' among others contribute to crime rate. This observation calls for further probe, so as to find a way of reducing crime rate in the country.
Table 4 below reveals that majority $61.3 \%$ of the respondents are remand prisoners (awaiting trial) while $38.7 \%$ were already convicted. Further probe reveals that the high number of awaiting trial prisoners was occasioned by the slow process of litigation in Nigeria. Some of the remand prisoners have been in prison for more than twelve (12) calendar months.

Table 5 below reveal that majority of the inmates $38.7 \%$ use the library sparingly, $29 \%$ do not use it at all; while $19.4 \%$ and $12.9 \%$ use it sometimes and often respectively. This revelation only confirms one's fear raised by Imade (2005) submission. How can people who are allowed outside once a week and who has no regular bath use the library. An unconfirmed suspicion is that those who use the library often are VIPs.

In measuring the level of adequacy, cognizance was taken of the respondents who claimed to have used the prison library at one time or the other. $59 \%$ of the respondents rated the library stock as inadequate. $36.4 \%$ saw it as fairly adequate, while only $13.6 \%$ rated it as adequate. This revelation is at variance from the expected level of library services in prisons. Prison libraries provide an important means of self-improvement and reformation for inmates. Many reports have demonstrated that prisoners feel that library service is valuable. For example, when one of the deadliest riots in penal history occurred in 1980, in Santa Fe, New Mexico, the inmates destroyed most of the prison's facilities but the library remained untouched. (Dixen \& Thorsen 2001). If prisoners value good library services, efforts should be geared towards the improvement of prison libraries stock.

Table 4: Category of Prisoners.

\begin{tabular}{|l|l|l|}
\hline Category & frequency & Percentage \\
\hline Convicted prisoners & 24 & 38.7 \\
\hline Remand prisoners & 38 & 61.3 \\
\hline Detainees & - & - \\
\hline Total & 62 & 100 \\
\hline
\end{tabular}

Table 5: Library use by inmates

\begin{tabular}{|l|l|l|}
\hline Usage & frequency & Percentage \\
\hline Often & 8 & 12.9 \\
\hline Sometimes & 12 & 19.4 \\
\hline Sparingly & 24 & 38.7 \\
\hline Never & 18 & 29.0 \\
\hline Total & 62 & 100 \\
\hline
\end{tabular}


Table 6: Adequacy of Library Stock

\begin{tabular}{|l|l|l|}
\hline Level & Frequency & Percentage \\
\hline Adequate & 6 & 13.6 \\
\hline Fairly Adequate & 16 & 36.4 \\
\hline Inadequate & 22 & 50.0 \\
\hline Total & 44 & 100 \\
\hline
\end{tabular}

Table 7: Importance of Information to Reformation and Rehabilitation of Prisoners

\begin{tabular}{|l|l|l|}
\hline Responses & Frequency & Percentage \\
\hline Strongly Agree (SA) & 10 & 16.1 \\
\hline Agree (A) & 34 & 54.8 \\
\hline Strongly Disagree (SD) & - & - \\
\hline Disagree (D) & 06 & 9.7 \\
\hline No Response & 12 & 19.4 \\
\hline Total & 62 & 100 \\
\hline
\end{tabular}

Table 8: Prisoners Desired Information

\begin{tabular}{|l|l|l|}
\hline Types of Information & Frequency & Percentage \\
\hline News/Current Affairs & 54 & 87.1 \\
\hline Legal Information & 38 & 61.3 \\
\hline Religious Information & 32 & 51.6 \\
\hline Psychological Information & - & - \\
\hline Recreational Information & 22 & 35.5 \\
\hline Vocational Information & 10 & 16.1 \\
\hline Educational Information & 44 & 67.8 \\
\hline
\end{tabular}

Table 7 above shows that majority of the prisoners agree that information is important to the objective of the prison services in rehabilitating and reforming them towards re-integration into the society. A closer look reveals that non-users of prison library services either disagree with the majority or refuse to respond.

In eliciting information for table 8 above , respondents were allowed, if need be to choose more than one option. From the table, it is observed that majority of the respondents $(87.1 \%)$ desire information on the current happenings in the society (News/Current Affairs), 67.8\% want educational information while $61.3 \%$ want legal information. $51.6 \%$ desire religious information, while $35.5 \%$ and $16.1 \%$ desire recreational and vocational information respectively. To one's chagrin, none of the respondents desire psychological information. This may be attributed to the respondents level of education and probably area of specialization in the case of those who had tertiary education.

\section{Summary Of Findings}

The under listed are the findings of this study into the adequate information provision in prison libraries in Nigeria. The questionnaire and observation method were the tools used in assessing the situation in the prisons used as case study.

a) Majority of the prisoners fall into the 2040 years age grade. b) Majority of them are Senior Secondary School Certificate holders

c) Majority of the inmates are still awaiting trials

d) Majority of the inmates use the library sparingly

e) The prison libraries stock are inadequate

f) The prison libraries are managed by non librarians

g) Despite their incarceration, inmates desire information on happenings in the society and also seek legal information. Probably to get informed and enlightened on their predicaments. They also desire information on personal development and recreation.

\section{Suggestions And Recommendation}

The following suggestions and recommendations are made from the study

i. Library Associations' visit to Prison Libraries: The National and various bodies/organs of the Nigerian Library Association (NLA) should as a matter of urgency start the organization of library visits and career talks for the prisoners and the warders. The NLA being a professional information body should take its services to the less privileged like the prisoners. To the prisoners, they will be enlightened on the benefits of information and arouse their interest in library use. This is with the intention of developing the individuals towards re-integration into the free society. 
The warders/officers will also benefit from such visits, as they will be enlightened on the benefits of library/information use; and they will also know the consequences of depriving the prisoners of information.

ii. Outreach Services by Public Libraries: The Nigerian constitution recognizes citizens' entitlement to 'due process of law'. However, when inmates are jailed, we tend to withdraw such rights indirectly. Apart from legal information, prisoners deserve other developmental information to ensure their readiness for re-absorption into the community. Public libraries should create outreach programme for the prisoners within their covered area. Librarians in charge of the outreach services will need to liaise with the prison officials and familiarize himself with the prison operations; so that he will not go beyond his 'legal' bounds in the provision of this service. In developed countries, such librarians do download information for inmates use Thorson and Dixen (2001).

iii. Provision of Adequately trained Library Personnel: The study found that the prison libraries are managed by prison officials who are not trained librarians. Librarianship, whether academic, public or prison is a profession and as such desires expertise in its operations. It is therefore recommended that prison libraries should be managed by professionals or prison officers who would have gone through trainings in librarianship.

iii. Towards improved collections: The library association should positively impact better funding of prison libraries by soliciting for the inclusion of library development in the prison's annual budget. This will enhance the desired improvement in the collection. Collections are developed by purchase, gifts and donations. Prison libraries should exploit the gifts and donations opportunity by soliciting for gifts and donations from philanthropic organizations and individuals, as well as libraries and information centres that weed their collections frequently.

iv. Readership Promotion Campaign

The library association and the public libraries should engage in readership promotion campaigns in prisons. Majority of the prisoners are school certificate holders and as such products of schools with inadequate library collections or without a library or reading room. Adetoro (2005) confirmed this when he submits that the problem facing school libraries include "inadequate facilities and equipment, inadequate and outdated materials, poor funding and poor accommodation. It is expected that readership promotions will arouse positive reading habits in the prisoners.

\section{References}

Adetoro, Niran (2005) 'A comparative analysis of school libraries development and use in selected public and private secondary schools in Ijebu and Remo Geo-Political zones of Ogun State. Lagos Journal of Library and Information Science Vol. 3 (1) pg. 7-15.

Akpe, A. I. (2004) Vision and Mission of the Nigerian Prisons Serivce Abuja, British Council/DFID 8p.

Anafulu, J. C (1998) Funding of University and Research Libraries in Nigeria. Policy Directions and options for the next century. (Research project for the award of member of NIPSS, Kuru) 90 pp.

Daramola, V. A. O. (2004) the Administration of Relief Materials in Prisons. A paper presented at the workshop for social pastoral workers in the prison by JDPC, Ibadan.

Dixen, Rebecca \& Thorson, Stephame (2001) "How librarians serve people in prison" Computers in Libraries; Vol. 21 (9) p. 48-53.

Grimes, Jonathan (2000) Rehabilitatioal versus Recreational Principles in Prison Libraries. A Masters Thesis submitted to the University of Northumbra, Newcastle.

Ibegwam, A. (2003) Nigerian Medical Libraries in a Digital Age: Lagos Journal of Library and Information Science 1 (2) 129-135.

Iloeje, M. U. (2001) Libraries and Librarians: making a difference in the knowledge Age in a compendium of papers presented at the 39th National Conference and AGM of the NLA: Owerri; NLA pg. 22-26.

Imade, James (2005) 'I was detained for eleven years without trial in Sunday comet, June 12.

Jarjoura, R.G., \& Krumholz, S.T. (1998) Combining Bibliotherapy and Positive Role Modeling as an Alternative to Incarceration. Journal of Offender Rehabilitation. 28 (1/2) 127-139

NPS/DFID (2002) State of prisons in Nigeria. 1st Nigerian Association Prisons Service - Civil Society Dialogue. (Action Plan Document for Nigerian Prison Service. Abuja, British Council/DFID 29p.

Oketunji, I (2005) Reference Services: Its functions and importance in libraries and information centers in a compendium of papers presented at the 2005 National Interactive Seminar, 20th28th April.

Shirley, G. L. (2003) Correctional Libraries, library Standards and Diversity. Journal of Correctional Education, Jun. Accessed electronically on $8^{\text {th }}$ August, 2006. 